\title{
Effect of a 5\% Neem Solution on the Presence of Ticks in Cattle in Two Locations in Jalisco, Mexico
}

\author{
Esther Albarrán-Rodríguez ${ }^{{ }^{*}}$, Paloma Del Rosario Del Real Quezada1, \\ Manuel Rosales Cortés ${ }^{1}$, Guillermo Nolasco Rodríguez ${ }^{1}$, Lucia García Delgado ${ }^{1}$, \\ Guillermo Ruíz Cano², Héctor Marcelo Cruz Alba²
}

\author{
${ }^{1}$ División de Ciencias Veterinarias, Centro Universitario de Ciencias Biológicas y Agropecuarias, Universidad de Guadalajara \\ Jalisco, Mexico \\ ${ }^{2}$ Laboratorios DESPPO. S.A. de C.V. Tepatitlán de Morelos, Jalisco, México \\ Email: *esther.albarran@academicos.udg.mx
}

How to cite this paper: Albarrán-Rodríguez E., Quezada, P.D.R.D.R., Cortés, M.R., Rodríguez, G.N., Delgado, L.G., Cano, G.R. and Alba, H.M.C. (2019) Effect of a 5\% Neem Solution on the Presence of Ticks in Cattle in Two Locations in Jalisco, Mexico. Open Journal of Veterinary Medicine, 9, 185-193.

https://doi.org/10.4236/ojvm.2019.912016

Received: November 4, 2019

Accepted: December 15, 2019

Published: December 18, 2019

Copyright $\odot 2019$ by author(s) and Scientific Research Publishing Inc. This work is licensed under the Creative Commons Attribution International License (CC BY 4.0).

http://creativecommons.org/licenses/by/4.0/

\begin{abstract}
The objective of this work was to evaluate the effect of a $5 \%$ neem extract on the presence of ticks. Forty creole cattle were used, divided into four groups: 2 experimental and 2 controls, in the towns of Cocula and El Chante, Jalisco. The tick count was by direct palpation, and with an acarometer $\left(25 \mathrm{~cm}^{2}\right)$. Eight body regions were evaluated: neck, thorax, flank and thigh, left and right. At zero time, after the initial tick count, it was applied by spraying and once, the $5 \%$ neem extract, at a dose of $10 \mathrm{ml} / \mathrm{L}$. Ticks were quantified at 7 , $14,21,28,35$ and 42 days post-treatment. The data were subjected to descriptive statistical analysis and Sum of Kruskal-Wallis Ranges $(\alpha=0.05)$ (SigmaStat 3.1). In Cocula, at zero time, the average of ticks was in neck 32, in thorax 64, in flanks 96 and in thighs 129 (average per animal 323 ticks). In subsequent sampling, the average decreased in the experimental group to 1 or 4 parasites. In "El Chante", an average of 60 ticks was found at the time of the neck, in the thorax 121, in flanks 181 and in thighs 242 (average per animal 600 ticks). In subsequent sampling, the average decreased in the experimental group, with averages of 1 to 4 . Statistical differences ( $p \leq 0.001$ ) were found between the groups. It can be concluded that $5 \%$ neem extract has a repellent and tick effect in cattle for at least 42 days.
\end{abstract}

\section{Keywords}

Tick, Boophilus, Neem, Azadirachta indica, Cattle 


\section{Introduction}

Ticks and diseases that they transmit are one of the main limitations of the exploitation of cattle in the world. The problem depends on the region, tick species present, transmitting agent, as well as the socioeconomic situation and technological progress in the application of control measures [1].

The most problematic ticks belong to the genera Boophilus and Amblyomma. The negative economic impact of livestock ticks is due to direct and indirect effects. Its direct effect on production is the result of damage to the skin due to the action of bites, blood loss and toxic effects. In addition, there is a direct effect on animal weight gain and milk production. Ticks also cause losses in livestock fertility, increased fattening time and difficulty in importing improved breeds to increase genetic quality in areas infested by ticks. The indirect effect is given by the agents that mainly transmit the tick of the genus Boophilus such as Babesia bovis, Babesia bigemina and Anaplasma marginale [2] [3].

Most of the parasitic ticks of cattle belong to the so-called "hard ticks" of the Ixodid family. Therefore, ticks are also sometimes referred to as "ixodicides" as almost-synonymous with ticks, for practical purposes [4] [5] [6].

Acaricides used against scabies mites are called "sarnicides." Most ticks (organophosphates, pyrethroids, amidines, phenylpyrazoles) act by simple contact (tarsal effect) of the compound with the tick. When cattle are treated (by bath, pour-on, etc.), the compound spreads through the animal's skin, comes into contact with the tick and kills them more or less quickly (shock effect) and for more or less time after application (residual effect) [7].

The effect or residual period of a tick indicates the period of time after the application of the product during which it continues to have an effect against ticks that infest the animal after being treated. Some compounds (endectocides, benzoylureas) also act systemically; that is, after being applied to the animal, they penetrate its blood flow and reach the ticks through the blood, since all the ticks feed on blood [8].

Ticks are especially harmful to cattle in warm, tropical and subtropical regions. Ticks of the following genera abound in them: Amblyomma, Boophilus (microplus) and Dermacentor [9].

There are the alternatives of control with organic repellents, based on natural extracts, which have demonstrated their ability to repel ectoparasites, in addition to causing their death by direct effects on the respiratory system, as well as by the denaturation of their external structure [8] [10].

In a recent literature review that includes neem (Azadirachta indica) and another 230 plants, bioactive properties are identified: toxic, repellent, anti-food, anti-ovipositants and the ability to immobilize various species of ticks. Therefore, they represent a potential in the development of sustainable, efficient and effective agents suitable for rural farmers against such ectoparasites [11].

The Neem (Azadirachta indica) is a tree belonging to the Meliaceae family native to the tropical countries of Southeast Asia commonly known as loamy, lilac of India and as Neem in English, the term has its origin in the Sanskrit Nimba 
Sarva red nivarini (curator of all diseases), is a medium to large sized tree that can reach a height of $30 \mathrm{~m}$, characterized by its short and straight shaft, a wrinkled bark of dark brown to gray and a dense and rounded crown with leaves Pinnate that has adapted to semi-arid climate zones, tolerates temperatures from $0^{\circ} \mathrm{C}$ to $49^{\circ} \mathrm{C}$, currently; it is grown in more than 50 countries, maintaining its characteristics and having a wide variety of uses [12] [13] [14].

The biologically active constituents of Neem such as terpenoids, (more specifically called limonoids), of which the most important are randomidactin, salanine, meliantrol, nimbine and nimbidin, which have been reported by various scientific studies to interrupt or inhibit the development of eggs, larvae and pupae; blocking in this way the change of larvae to nymphs; repels larvae and adults; repels females to oviposit; sterilize adults; poison larvae and adults; deter insects to feed; It confuses insects to perform metamorphosis and inhibits the formation of chitin [15] [16].

Neem contains certain substances that make it act in various ways such as the ecdysome, which alters the behavior in the vital processes of insects. Another component is salanine, which is reported to have a repellent effect or activity. In addition, neem has also been observed to have an acaricidal, nematicidal and fungicidal action on oily preparations [17] [18].

It is important to mention that the neem compounds are easy to biodegrade so they do not leave polluting toxic residues and there is no accumulation of the active ingredients in the food chain, nor does it leave residues in the soil or in plant products when used in these as pesticide or disinfectants [10] [19] [20].

Taking into account all the benefits and benefits offered by neem in the present study, a new commercial organic product based on neem extract, added with oils and natural fixatives (IXODES ${ }^{\circledR}$ ) was applied to evaluate its ability as a repellent and tick to the be applied by sprinkling in cattle.

\section{Objective}

The objective of this work was to evaluate the tick-repellent effect of a 5\% neem solution in cattle on two farms in areas with ticks in Jalisco, Mexico.

\section{Materials and Methods}

Study location

The present experimental study was carried out in two populations of the state of Jalisco, due to its geographical location, presence of ticks and willingness of farmers to participate in the test: in Cocula $\left(20^{\circ} 14^{\prime} 30^{\prime \prime}\right.$ at $20^{\circ} 30^{\prime} 30^{\prime \prime}$ north latitude and $103^{\circ} 45^{\prime} 00^{\prime \prime}$ a at $103^{\circ} 55^{\prime} 00^{\prime \prime}$ west longitude), semi-dry, dry and semi-dry climate, with an average annual temperature of $19^{\circ} \mathrm{C}$, an average annual rainfall of $95.4 \mathrm{~mm}$ and 1320 meters above sea level. And in "El Chante, Autlán Municipality $\left(19^{\circ} 34^{\prime} 30^{\prime \prime}\right.$ at $19^{\circ} 53^{\prime} 45^{\prime \prime}$ north latitude and $104^{\circ} 07^{\prime} 00^{\prime \prime}$ at $104^{\circ} 27^{\prime} 00^{\prime \prime}$ west longitude), it has a semi-dry and dry climate, semi-warm, with an average temperature of $23.2^{\circ} \mathrm{C}$, an average annual rainfall of $816 \mathrm{~mm}$ and an altitude of $900 \mathrm{me}-$ ters above sea level [21]. 
Description of the animals

A total of 40 creole cattle (crosses Cebuinos - Holstein, Charolais), of both genders and different ages (10 to 18 months) were used, which had a month and a half without handling or applying traditional ticks, were divided into two groups: experimental and control $(n=10)$ in the two populations, the duration of the study was 42 days, during the months of greatest infestation that are May-June. All animals received the same grazing management on farms nestled in areas with presence of ticks of the genus Boophilus, with infestations ranging from 320 to 600 parasites per head.

Preparation and application of the neem solution

The preparation of the mixture for bathing the experimental animals was carried out as follows: the $5 \%$ neem extract was diluted (Ixodes ${ }^{\circledast}$, DESPPO Laboratories; organic product whose formula is: $1.5 \%$ coconut amide, neem extract $5.0 \%$ and $93.5 \%$ of conditioners and diluents) at a dose of $10 \mathrm{ml}$ per liter of water, with a $\mathrm{pH}$ between 7.5 to 9 since in preliminary laboratory tests it proved to have a better effect when prepared in water with a $\mathrm{pH}$ alkaline, for this reason in areas where it is known that the water tends to be acidic or with a $\mathrm{pH}$ less than 7.0 it is recommended after washing the backpacks and using an applicator with nozzles of the number 8003 that give a breeze spray, add $20 \mathrm{~g}$, of common sodium bicarbonate for every 20 liters of water before including the neem mixture, this guarantees a better product result.

Quantification of the number of ticks

To determine and evaluate the onset of the repellent and tick effect in animals, the number of ticks per animal was counted. The count of ticks attached to the bovine was made by direct palpation and with the use of an acarometer, made by an acetate sheet with a rectangular groove $5 \mathrm{~cm}$ wide by $5 \mathrm{~cm}$ long, that is, with an area of $25 \mathrm{~cm}^{2}$. Four areas of the bovine body surface were evaluated: neck, thorax, flank and thigh, left and right giving a total of eight fields per animal. The quantification was carried out at the beginning of the study and later every week, for 42 days (Table 1). Randomly, samples were taken of some specimens of knocked down ticks of the animal and their stage was determined by a stereomicroscope analyzing their morphology.

Statistic analysis

For the analysis of the data, the Sigma Stat 3.1 program was used to compare the experimental group against the control group in the body regions previously established in the methodology using a non-parametric statistical test since the values did not behave as a normal population, called Mann-Whitney rank sum test with a significance level of 0.05 .

Table 1. Format for field data recording.

\begin{tabular}{cccccccccccc}
\hline Number & Race & Neck & Neck & Thorax & Thorax & Flank & Flank & Thigh & Thigh & Total \\
\hline & Left & Right & Left & Right & Left & Right & Left & Right & \\
\hline
\end{tabular}




\section{Results}

At the farm in Cocula, Jalisco, after the first week after the application of the drug, a random sample of the knocked down ticks $(n=50)$ was taken to determine the stage in which these ectoparasites were found, observing the following: 26 were Young females, 2 young males, 3 were adult males, 4 nymph females, 6 nymph males, and 9 were full or engulfed adult females and regardless of the stage, all showed deformation in the idiosome area with discoloration.

At 14 days after application, another sample of knocked down ticks was taken at random with one $(\mathrm{n}=50)$ observing the following: 19 were young females, 5 young males, 3 were adult males, 5 nymph females, 4 nymph males and 14 They were full or engulfed adult females and also had deformation in the area of the idiosome with discoloration.

When comparing the results of the groups, regardless of the stage of the ticks, it was found that for the herd of Cocula on day zero the animals presented a strong presence of ticks with an average of 323 in both groups. After the application of the neem solution, a marked decrease in infestation was observed at 7 and up to 42 days, with averages of 6 to 1 ticks in the experimental group and with statistical differences $(\mathrm{p}<0.001)$ in relation to the control group, which presented higher averages of ectoparasites in subsequent weeks (323 - 485 ticks per animal) (Table 2).

A similar behavior was found in the bovine group of "El Chante", Jalisco. When comparing the groups, it was found that by day zero, the animals had a strong presence of ticks with averages of 606 and 600 for the experimental and control groups, respectively. After the application of neem, a marked decrease in infestation was observed in the experimental group at 7 and up to 42 days, with averages of 6 to 4 ticks per animal and with statistical differences $(\mathrm{p}<0.001)$ in relation to the group control that followed with averages of 707 to 880 (Table 3 ).

Infestation in untreated groups, in both populations, presented a similar behavior, the body areas with the highest number of ticks were, in increasing order: thighs, flanks, thorax and neck (Table 2 and Table 3 ).

\section{Discussion}

The state of Jalisco, Mexico, is in the control phase of ticks (Boophilus spp.), That is to say, important efforts are made by both the government and the related farmers and professionals to reduce and control said ectoparasite [22].

Some of the actions carried out consist of: Mobilization control; Rational pesticide management and resistance prevention activities; have a sampling and monitoring system to monitor the infestation of cattle by ticks, the diseases they transmit, as well as the resistance of ticks to ixodicide, in response to the "Agreement establishing the National Campaign against Tick Boophilus spp" [22].

Tick control due to its economic and animal health impact is of great importance [23]. Therefore, it is essential to look for sustainable and efficient strategies such as the use of plant extracts [11], in particular neem extracts or solutions. 
Table 2. Effect of $5 \%$ neem solution on the presence of ticks by body area in cattle, Cocula, Jalisco.

\begin{tabular}{|c|c|c|c|c|c|c|c|c|}
\hline \multicolumn{2}{|c|}{ Groups and body area* } & $\begin{array}{c}0 \text { days } \\
\text { Average } \pm \\
\text { Standard } \\
\text { deviation }\end{array}$ & $\begin{array}{c}7 \text { days } \\
\text { Average } \pm \\
\text { Standard } \\
\text { deviation }\end{array}$ & $\begin{array}{c}14 \text { days } \\
\text { Average } \pm \\
\text { Standard } \\
\text { deviation }\end{array}$ & $\begin{array}{c}21 \text { days } \\
\text { Average } \pm \\
\text { Standard } \\
\text { deviation }\end{array}$ & $\begin{array}{c}28 \text { days } \\
\text { Average } \pm \\
\text { Standard } \\
\text { deviation }\end{array}$ & $\begin{array}{c}35 \text { days } \\
\text { Average } \pm \\
\text { Standard } \\
\text { deviation }\end{array}$ & $\begin{array}{c}42 \text { days } \\
\text { Average } \pm \\
\text { Standard } \\
\text { deviation }\end{array}$ \\
\hline \multirow{3}{*}{$\begin{array}{l}\text { Control or } \\
\text { witness group }\end{array}$} & Neck & $32.40 \pm 1.48$ & $49.48 \pm 1.81$ & $37.36 \pm 1.36$ & $23.22 \pm 0.85$ & $30.30 \pm 1.11$ & $40.40 \pm 1.48$ & $48.48 \pm 1.77$ \\
\hline & Thorax & $64.60 \pm 2.21$ & $98.98 \pm 3.62$ & $74.74 \pm 2.73$ & $46.46 \pm 1.70$ & $60.60 \pm 2.21$ & $80.80 \pm 2.95$ & $96.96 \pm 3.54$ \\
\hline & Flank & $96.70 \pm 3.29$ & $148.45 \pm 5.06$ & $112.18 \pm 3.82$ & $69.69 \pm 2.38$ & $90.90 \pm 3.10$ & $121.20 \pm 4.13$ & $145.44 \pm 4.96$ \\
\hline \multirow{2}{*}{\multicolumn{2}{|c|}{ Total ${ }^{\star *}$}} & $129.20 \pm 4.43$ & $197.96 \pm 7.23$ & $149.48 \pm 5.46$ & $92.92 \pm 3.39$ & $121.20 \pm 4.43$ & $161.60 \pm 5.90$ & $193.92 \pm 7.08$ \\
\hline & & $323 \pm 23.61$ & $495 \pm 36.15$ & $374 \pm 27.30$ & $232 \pm 16.97$ & $303 \pm 22.13$ & $404 \pm 29.51$ & $485 \pm 35.41$ \\
\hline \multirow{4}{*}{$\begin{array}{l}\text { Experimental } \\
\text { Group }\end{array}$} & Neck & $32.32 \pm 1.81$ & $0.54 \pm 0.69$ & $0.30 \pm 0.32$ & 0 & 0 & $0.10 \pm 0.32$ & $0.10 \pm 0.32$ \\
\hline & Thorax & $64.64 \pm 2.36$ & $1.28 \pm 0.67$ & $0.40 \pm 0.42$ & 0 & $0.20 \pm 0.31$ & $0.30 \pm 0.48$ & $0.50 \pm 0.48$ \\
\hline & Flank & $96.96 \pm 3.30$ & $1.91 \pm 0.81$ & $0.50 \pm 0.48$ & $0.10 \pm 0.32$ & $0.10 \pm 0.31$ & $0.40 \pm 0.48$ & $1.0 \pm 0.52$ \\
\hline & Thigh & $129.28 \pm 4.72$ & $2.26 \pm 1.10$ & $0.30 \pm 0.42$ & $0.50 \pm 0.48$ & $0.30 \pm 0.31$ & $1.0 \pm 0.52$ & $1.90 \pm 0.57$ \\
\hline \multicolumn{2}{|c|}{ Total ${ }^{\star \star}$} & $323 \pm 23.61$ & $6 \pm 4.69$ & $2 \pm 1.08$ & $1 \pm 0.96$ & $1 \pm 0.96$ & $2 \pm 0.63$ & $4 \pm 0.89$ \\
\hline
\end{tabular}

$\left.{ }^{*}\right)$ average and standard deviation of ticks by body area, group and sampling period, statistical differences $(\mathrm{p}<0.001)$ from day 7 . $\left({ }^{*}\right)$ average and standard deviation of ticks per animal, statistical differences $(\mathrm{p}<0.001)$ from day 7.

Table 3. Effect of $5 \%$ neem solution on the presence of ticks by body area in cattle, El Chante, Jalisco.

\begin{tabular}{|c|c|c|c|c|c|c|c|c|}
\hline \multicolumn{2}{|c|}{ Groups and body area* } & $\begin{array}{c}0 \text { days } \\
\text { Average } \pm \\
\text { Standard } \\
\text { deviation }\end{array}$ & $\begin{array}{c}7 \text { days } \\
\text { Average } \pm \\
\text { Standard } \\
\text { deviation }\end{array}$ & $\begin{array}{c}14 \text { days } \\
\text { Average } \pm \\
\text { Standard } \\
\text { deviation }\end{array}$ & $\begin{array}{c}21 \text { days } \\
\text { Average } \pm \\
\text { Standard } \\
\text { deviation }\end{array}$ & $\begin{array}{c}28 \text { days } \\
\text { Average } \pm \\
\text { Standard } \\
\text { deviation }\end{array}$ & $\begin{array}{c}35 \text { days } \\
\text { Average } \pm \\
\text { Standard } \\
\text { deviation }\end{array}$ & $\begin{array}{c}\text { 42 days } \\
\text { Average } \pm \\
\text { Standard } \\
\text { deviation }\end{array}$ \\
\hline \multirow{4}{*}{$\begin{array}{l}\text { Control or } \\
\text { witness group }\end{array}$} & Neck & $60.60 \pm 2.21$ & $70.70 \pm 2.58$ & $65.64 \pm 2.40$ & $52.52 \pm 1.92$ & $58.58 \pm 2.14$ & $63.62 \pm 2.32$ & $80.80 \pm 2.95$ \\
\hline & Chest & $121.20 \pm 4.43$ & $141.40 \pm 5.16$ & $131.30 \pm 4.80$ & $105.04 \pm 3.84$ & $117.16 \pm 4.28$ & $127.26 \pm 4.65$ & $161.60 \pm 5.90$ \\
\hline & Flank & $181.80 \pm 6.20$ & $212.10 \pm 7.23$ & $196.95 \pm 6.71$ & $157.56 \pm 5.37$ & $187.46 \pm 6.85$ & $190.89 \pm 6.51$ & $242.12 \pm 8.26$ \\
\hline & Thigh & $242.40 \pm 8.85$ & $282.80 \pm 10.33$ & $262.60 \pm 9.59$ & $210.04 \pm 7.67$ & $234.16 \pm 8.56$ & $254.52 \pm 9.30$ & $323.20 \pm 11.81$ \\
\hline \multicolumn{2}{|c|}{ Total $^{\star *}$} & & $707 \pm 51.65$ & $657 \pm 47.96$ & $525 \pm 38.36$ & $586 \pm 42.80$ & $636 \pm 46.48$ & $808 \pm 59.02$ \\
\hline \multirow{4}{*}{$\begin{array}{c}\text { Experimental } \\
\text { Group }\end{array}$} & Neck & $60.60 \pm 2.21$ & $0.54 \pm 0.67$ & $0.30 \pm 0.32$ & 0 & 0 & $0.10 \pm 0.32$ & $0.10 \pm 0.32$ \\
\hline & Chest & $121.20 \pm 4.43$ & $1.38 \pm 0.79$ & $0.20 \pm 0.42$ & $0.10 \pm 0.32$ & 0 & $0.30 \pm 0.48$ & $0.70 \pm 0.52$ \\
\hline & Flank & $181.80 \pm 6.20$ & $1.92 \pm 0.68$ & $0.40 \pm 0.48$ & $0.10 \pm 0.32$ & $0.40 \pm 0.42$ & $0.40 \pm 0.48$ & $0.70 \pm 0.48$ \\
\hline & Thigh & $242.40 \pm 8.85$ & $2.76 \pm 0.86$ & $0.60 \pm 0.48$ & $0.40 \pm 0.42$ & $0.20 \pm 0.32$ & $1.00 \pm 0.52$ & $2.00 \pm 0.57$ \\
\hline \multicolumn{2}{|c|}{ Total ${ }^{* *}$} & $600 \pm 44.27$ & $6.0 \pm 4.50$ & $2 \pm 1.08$ & $1 \pm 0.96$ & $1 \pm 0.96$ & $2.0 \pm 0.63$ & $4 \pm 0.85$ \\
\hline
\end{tabular}

$\left(^{*}\right)$ average and standard deviation of ticks by body area, group and sampling period, statistical differences $(\mathrm{p}<0.001)$ from day 7 . $\left(^{* *}\right)$ average and standard deviation of ticks per animal, statistical differences $(\mathrm{p}<0.001)$ from day 7 .

In the present study, when analyzing the random sample of 50 ticks knocked down on days 5 and 14 after application according to the biological cycle, the highest prevalence was of young females followed by teleogins (females, swollen full of blood and eggs) in both localities of Jalisco [24].

It is known that according to the biological cycle the ticks detach from the animal at approximately 22 days in the teleogin stage, which is when for a week they feed on the animal's blood after it falls to the ground they ovipocyte and die 
and as observed according to At the results the treatment in experimental animals, the commercial mixture of neem, was effective long before they reached this stage, interrupting the cycle [25].

Based on the data obtained from the field tests in the animals of the control group, from both villages, the tick infestation did not decrease during the entire duration of the study, the behavior was the same. It is important to note that the premises where these field tests were carried out have a history that for a long time used applications of "traditional chemical" products, of the three families in our country (organophosphorus, amidines and pyrethroids) that are reported as ticks [7].

With the intention of obtaining better results, the farmers repeated the application of the traditional tick products every 7 days and reported that there was a strong resistance to these substances despite the fact that they rotated the products to avoid this resistance, with this they tried to obtain better results, they also reported that in most cases the dosage they used was already twice the original dose to obtain better results, although this represented a greater risk for both the animal and the individual who applies it, using special equipment to its management, preparation and application and greater economic expenditure [8].

On the contrary, the experimental group bathed with the commercial mixture of neem, at the beginning of the study it was observed that in the first seven days after the application of the product the ticks detached from the body of the animal to the extent of observing one or two ticks only in some of the inspected areas which demonstrated that the formula made with Neem extract has an effect as a tick was immediate [25] [26].

It was also observed that as time went by the effect of the commercial mixture of neem, as a repellent against ticks in animals that were bathed with this product, was maintained during the six weeks, although the study began at the beginning of the rainy season, during which the humidity and heat increase in the area due to its geographical location and the climatic characteristics that result in this combination a high degree of animal infestation by ticks [7].

\section{Conclusions}

The commercial $5 \%$ neem product had a good tick effect from the first week of application. The mixture maintained a repellent effect for 6 weeks according to the results.

The commercial mixture of 5\% neem represents an alternative for the control of ticks in cattle without having adverse effects for the animal by toxicity, for the applicator and/or in the environment, because it is a harmless product, of organic origin and biodegradable.

\section{Conflicts of Interest}

The authors declare no conflicts of interest regarding the publication of this paper. 


\section{References}

[1] Porfirio, N.I. and Schwentesius, R.R. (2016) Biological Control of Ticks (Boophilus microplus), with Microorganisms. CIESTAM Autonomous University of Chapingo, Mexico State. https://www.researchgate.net/publication/289768055

[2] Araque, A., Ujueta, S., Bonilla, R., Gómez, D. and Rivera, J. (2014) Acaricidal Resistance of Rhipicephalus (Boophilus) Microplus in Some Colombian Cattle Farms. U.D.C.A Magazine News \& Scientific Dissemination, 17, 161-170.

[3] Benavides, O.P., Romero, P. and Villamil, J. (2016) Cattle Ticks and Disease Agents that Transmit in Epidemiological Scenarios of Climate Change: Guide for Tick Management and Climate Change Adaptation. Inter-American Institute for Cooperation on Agriculture (IICA), University of La Salle, Philadelphia, PA.

[4] Benavides-Montaño, J.A., Jaramillo-Cruz, C.A. and Mesa-Cobo, N.C. (2018) Ticks Ixodidae (Acari) in Valle del Cauca, Colombia. Boletín Científico. Centro de $\mathrm{Mu}$ seos. Museo de Historia Natural, 22, 131-150.

[5] Solari, M.A., Cuore, U., Trelles, A. and Mautone, G. (2006) Taxonomy of the 5 Genera of Ticks Diagnosed in Cattle in Uruguay. Conference Contributions to the Fight against Ticks, Department of Parasitology, Uruguay. http://www.mgap.gub.uy/sites/default/files/multimedia/1803_19_taxonomc3ada_de _los_5_gc3a9neros_de_garrrapatas_diagnosticadas_en_0.pdf

[6] Polanco-Echeverry, D.N. and Ríos-Osorio, L.A. (2016) Biological and Ecological Aspects of Hard Ticks. Corpoica Ciencia y Tecnología Agropecuaria, 17, 81-95.

[7] Schleske, I. (2011) Prevalence of Production Units with Rhipicephalus (boophilus) Microplus Ticks Resistant to Amidines and Risk Factors Associated with Their Presentation in the Central Region of the State of Veracruz. Master Thesis, Faculty of Veterinary and Zootechnical Medicine, Universidad Veracruzana, Mexico.

[8] Rodríguez-Vivas, R.I., Rosado-Aguilar, J.A., Ojeda-Chi, M.M., Pérez-Cogollo, L.C., Trinidad-Martínez, I. and Bolio-González, M.E. (2014) Integrated Control of Ticks in Bovine Livestock. Ecosystems and Agricultural Resources, 1, 295-309.

[9] Faccioli, V. (2011) Ticks (Acari, Ixodidae and Argasidae) from the Invertebrate Collection. Series Catalogs 25, Provincial Museum of Natural Sciences "Florentino Ameghino".

[10] Orozco, F. and Rodríguez, M. (2007) Azadirachta Suspension Cell Cultures Indicated for the Production of a Bioinsecticide. Mexican Journal of Chemical Engineering, 6, 251-258.

[11] Wanzala, W. (2017) Potential of Traditional Knowledge of Plants in the Management of Arthropods in Livestock Industry with Focus on (Acari) Ticks. Evidence-Based Complementary and Alternative Medicine, 2017, Article ID: 8647919. https://doi.org/10.1155/2017/8647919

[12] Estrada, J., López, M.T. and Puig, N. (2009) El Nim, a Sustainable Agroecological Alternative. Technical Manual. New Extended Edition, 32.

[13] Fernández, D.S.R., Villarroel, A., Cuamo, L. and Storaci, V. (2016) Evaluation of a Somatic Embryogenesis Regeneration System for Neem (Azadirachta indica). Acta Biológica Colombiana, 21, 581. https://doi.org/10.15446/abc.v21n3.52626

[14] García, M.Y., Castro, G.M., López, M.M., Cárdenas, R.E. and Molina, B.R. (2017) Effect of Leaf Extract Neem (Azadirachta indica) for Controlling Ectoparasites in Dogs. Scientific Journal, 27, 154-161.

[15] Angulo, E.M.A., Gardea, B.A.A., Vélez, R.R., García, E.R.S., Carrillo, F.A., Cháidez, Q.C. and Departure, L.J.I. (2004) Azadirachtin Content in Neem Seeds (Azadirachta 
indica A. Juss) Collected in Sinaloa, Mexico. Magazine Fitotecnia Mexicana, 27, 305-311.

[16] Broglio-Micheletti, S.M., Dias, N., Valente, E.C., de Souza, L.A., Lopes, D.O. and Dos Santos, J.M. (2010) Action of Extract and Oil Neem in the Control of Rhipicephalus (Boophilus) Microplus (Canestrini, 1887) (Acari: Ixodidae) in Laboratory. Brazilian Journal of Veterinary Parasitology, 19, 44-48. https://doi.org/10.1590/S1984-29612010000100009

[17] Esparza-Díaz, G., López-Collado, J., Villanueva-Jiménez, J.A., Osorio-Acosta, F., Otero-Colina, G. and Camacho-Díaz, E. (2010) Azadirachtin Concentration, Insecticide Efficacyand Phytotoxicity of Four Neem Azadirachta indica A. Juss. Extracts Agrociencia, 44, 821-833.

[18] Isea, G.A., Rodríguez, I.E. and Hernández, A.H. (2013) Tick Control Activity of Azadirachta Indicates A. Juss. (Neem). Cuban Journal of Medicinal Plants, 18, 327-340.

[19] Estrada-Peña, A. (2015) The Arachnida Class Ticks Order Ixodida: Manual, IDE Magazine. SEA, 13, 1-15.

[20] Gonzalez, M.M., Márquez, A.A., Melendéz, C.E. and Lopez-Ortega, A.A. (2012) Effect of Neem Leaf Extract (Azadirachta indica A. Juss) on Streptozotocin-Induced Diabetes Mellitus in Mice. Veterinary Science Gazette, 15, 64-71.

[21] INAFED National Institute for Federalism and Municipal Development (2010) Encyclopedia of the Municipalities and Delegations of Mexico.

https://mexicangenealogy.info/encyclopedia-of-municipalities-and-delegations-formexico/

[22] D.O.F. Diario Oficial de la Federación (2013) Acuerdo por el que se establece la Campaña Nacional para el control de Garrapata Boophilus spp. http://www.dof.gob.mx/nota_detalle.php? codigo=5292616\&fecha $=19 / 03 / 2013$

[23] Rajput, Z.I., Hu, S., Chen, W., Arijo, A.G. and Xiao, C. (2006) Importance of Ticks and Their Chemical and Immunological Control in Livestock. Journal of Zhejiang University, 7, 912-921. https://doi.org/10.1631/jzus.2006.B0912

[24] Álvarez, V. and Bonilla, R. (2007) Adults and Nymphs of the Tick Amblyomma cajennense fabricius (Acari: Ixodidae) in Horses and Cattle. Costa Rican Agronomy, 31, 61-69.

[25] Rodríguez-Vivas, R.I., Rosado-Aguilar, A., Basto, G., García, V.Z.S., Rosario, C.R. and Fragoso, S.H. (2006) Technical Manual for the Control of Ticks in Cattle. Technical Publication No. 4, National Research Center in Parasitology, Faculty of Veterinary Medicine and Zootechnics, Universidad Autónoma de Yucatán, Mexico.

[26] Villamil, D.A., Naranjo, N. and Van Strahlen, M.A. (2012) Insecticidal Effect of Neem Seed Extract (Azadirachta indica A. Juss) on Collaria scenica Stal (Hemiptera: Miridae). Entomologistas do Brasil, 5, 125-129.

https://doi.org/10.12741/ebrasilis.v5i2.224 